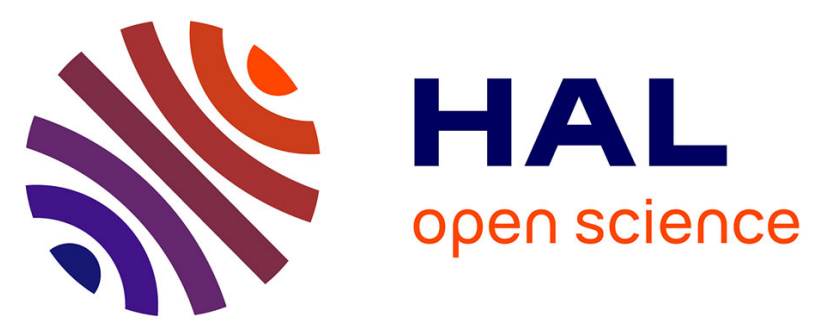

\title{
Influence of environmental changes on the biogeochemistry of arsenic in a soil polluted by the destruction of chemical weapons: A mesocosm study
}

Hugues Thouin, Fabienne Battaglia-Brunet, Marie-Paule Norini, Lydie Le

Forestier, Mickael Charron, Sébastien Dupraz, Pascale Gautret

\section{To cite this version:}

Hugues Thouin, Fabienne Battaglia-Brunet, Marie-Paule Norini, Lydie Le Forestier, Mickael Charron, et al.. Influence of environmental changes on the biogeochemistry of arsenic in a soil polluted by the destruction of chemical weapons: A mesocosm study. Science of the Total Environment, 2018, 627, pp.216-226. 10.1016/j.scitotenv.2018.01.158 . insu-01700628

\section{HAL Id: insu-01700628 \\ https://hal-insu.archives-ouvertes.fr/insu-01700628}

Submitted on 12 Feb 2018

HAL is a multi-disciplinary open access archive for the deposit and dissemination of scientific research documents, whether they are published or not. The documents may come from teaching and research institutions in France or abroad, or from public or private research centers.
L'archive ouverte pluridisciplinaire HAL, est destinée au dépôt et à la diffusion de documents scientifiques de niveau recherche, publiés ou non, émanant des établissements d'enseignement et de recherche français ou étrangers, des laboratoires publics ou privés. 


\section{Influence of environmental changes on the biogeochemistry of arsenic in a soil polluted by the destruction of chemical weapons: \\ a mesocosm study}

Hugues Thouin ${ }^{a, b, c, d}$, Fabienne Battaglia-Brunet ${ }^{a, b, c, d}$, Marie-Paule Norini ${ }^{\text {b,c,d }}$, Lydie Le Forestier $^{\mathrm{b}, \mathrm{c}, \mathrm{d}}$, Mickael Charron ${ }^{\mathrm{a}}$, Sébastien Dupraz ${ }^{\mathrm{a}}$ and Pascale Gautret ${ }^{\mathrm{b}, \mathrm{c}, \mathrm{d}}$

${ }^{\text {a }}$ BRGM, 3 avenue Claude Guillemin, 45060 Orléans, France

b Université d'Orléans, ISTO, UMR 7327, 45071 Orléans, France

${ }^{\mathrm{c}}$ CNRS, ISTO, UMR 7327, 45071 Orléans, France

d BRGM, ISTO, UMR 7327, BP 36009, 45060 Orléans, France

\section{Highlights}

- The surface of the main $\mathrm{As}, \mathrm{Cu}$ and $\mathrm{Zn}$ carrier was alterated in water saturated conditions

- Precipitation of $\mathrm{As}(\mathrm{V})$-bearing mineral mimetite contributed to the immobilization of $\mathrm{As}$ and $\mathrm{Pb}$

- The addition of OM contributed to the growth of As transformation microorganisms

- $\quad$ As(III)-oxidizing activity was decreased by OM but remained the major As transformation phenomenon in the system.

\section{Graphical abstract}
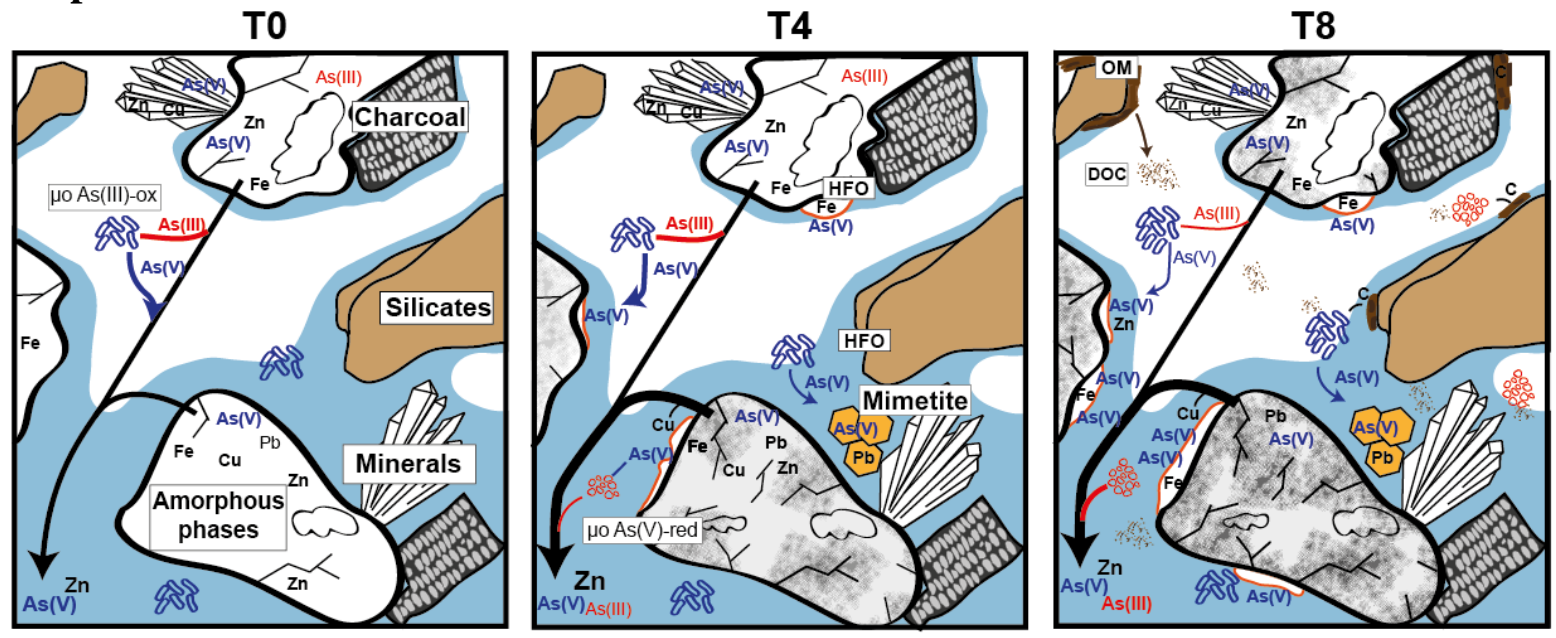

\section{Abstract}

Thermal destruction of chemical munitions from World War I led to the formation of a heavily contaminated residue that contains an unexpected mineral association in which a microbial As transformation has been observed. A mesocosm study was conducted to assess the impact of water saturation episodes and input of bioavailable 
organic matter $(\mathrm{OM})$ on pollutant behavior in relation to biogeochemical parameters. Over a period of about eight (8) months, the contaminated soil was subjected to cycles of dry and wet periods corresponding to water table level variations. After the first four (4) months, fragmented litter from the nearby forest was placed on top of the soil. The mesocosm solid phase was sampled by three rounds of coring: at the beginning of the experiment, after four (4) months (before the addition of $\mathrm{OM}$ ), and at the end of the experiment. Scanning electron microscopy coupled to energy dispersive X-ray spectroscopy observations showed that an amorphous phase, which was the primary carrier of $\mathrm{As}, \mathrm{Zn}$, and $\mathrm{Cu}$, was unstable under water-saturated conditions and released a portion of the contaminants in solution. Precipitation of a lead arsenate chloride mineral, mimetite, in soils within the water saturated level caused the immobilization of $\mathrm{As}$ and $\mathrm{Pb}$. Mimetite is a durable trap because of its large stability domain; however, this precipitation was limited by a low $\mathrm{Pb}$ concentration inducing that high amounts of As remained in solution. The addition of forest litter modified the quantities and qualities of soil OM. Microbial As transformation was affected by the addition of OM, which increased the concentration of both As(III)-oxidizing and As(V)-reducing microorganisms. The addition of OM negatively impacted the As(III) oxidizing rate, however As(III) oxidation was still the dominant reaction in accordance with the formation of arsenate-bearing minerals.

Keywords: Arsenic, metal, mineral stability, microbial arsenic transformation, organic matter, dry/wet cycles, mesocosm study 


\section{Introduction}

2 At the end of the First World War (1914-1918), the former combatants had large stockpiles of unfired munitions.

3 These unspent weapons were dismantled to recycle reusable material, then destroyed or abandoned by ocean

4 dumping or land burial. Chemical weapons containing nitroaromatic, chlorine, bromine or arsenical compounds

5 were destroyed primarily by burning because of their hazardous nature. The site called "Place-à-Gaz", located

6 northeast of Verdun (France), is one of many sites along the western front line where chemical shells were

7 destroyed. Between 1920 and 1928, approximately 200,000 shells containing organo-arsenic compounds were

8 subjected to simple thermal treatment (Bausinger et al., 2007). The burnt munitions were primarily "blue cross

9 shells" filled with arsenic-bearing vomiting agents CLARK I (diphenylchloroarsine) and CLARK II

10 (diphenylcyanoarsine).

11 Thermal treatment resulted in severe As and heavy metal contamination of the upper $10-40 \mathrm{~cm}$ of topsoil at the site (Bausinger et al., 2007; Thouin et al., 2016). The surface layer where the inorganic contaminants are concentrated corresponds to the combustion residues of the munitions. This layer, composed of slag, scoria, various munitions elements, and large amounts of ash and charcoal from the firewood used for burning, is black in color (Bausinger et al., 2007; Thouin et al., 2016). The central part of the site was heavily contaminated with As, Zn, $\mathrm{Cu}$, and $\mathrm{Pb}$; concentrations of these elements reached 72,820 mg.kg-1, 90,190 mg.kg-1, 9,113 mg.kg ${ }^{-1}$ and $5,777 \mathrm{mg} \cdot \mathrm{kg}^{-1}$, respectively (Thouin et al., 2016). Most organo-arsenic agents/compounds were oxidized during combustion, resulting in the release of inorganic arsenic $\mathrm{As}_{2} \mathrm{O}_{3}$ and $\mathrm{As}_{2} \mathrm{O}_{5}$ (Bausinger et al., 2007). A previous study by Thouin et al., (2016) showed that As was principally present as the pentavalent form $(\operatorname{As}(\mathrm{V}))$ within the solid phases (about $98 \%$ of arsenate and $2 \%$ of arsenite (As(III))) and that several arsenate minerals (adamiteolivenite series and pharmacosiderite) crystallized as the material cooled. An amorphous phase rich in $\mathrm{Fe}, \mathrm{Zn}, \mathrm{Cu}$, and As and presenting a vitreous texture was also observed, highlighting the association of this unusual mineral assemblage with thermal treatment.

24 Microorganisms actively contributing to the metabolism of carbon and arsenic were detected at the site despite low organic matter (OM) bioavailability (Thouin et al., 2016). Microbial activity plays a major role in As speciation in soils (de Mello et al., 2007; Yamamura et al., 2009). For example, in mining environment, microbial As-transforming activity was used in biomining of As-bearing minerals and to clean up post mining contamination 
reduction (Battaglia-Brunet et al., 2002; Bachate et al., 2012; Zobrist et al., 2000; Stolz et al., 2002), thus driving

30 As mobility and bioavailability. Changes in environmental conditions, such as modifications of Eh or $\mathrm{pH}$, are

31 likely to modify these microbial activities. Moreover, the concentration and the composition of soil OM affect a

32 microorganism diversity and biomass (Tiedje et al., 1999) and may impact bacterial As transformation (Bachate

33 et al., 2012; Lescure et al., 2016). The cyclic saturation of soils was shown to induce the mobility and change of

34 speciation of arsenic in relation with bacterial activities. Fe and As reduction and release were observed during

35 flooding of contaminated soil (Weber et al., 2010) or redox oscillations (Couture et al., 2015). As-transforming

36 microbes contribute actively to the transformation of As species in frequently saturated soils such as paddy fields

37 (Xiao et al, 2016). However, up to now, the activity of As(III)-oxidizing and As(V)-reducing microorganisms has

38 not been evaluated in highly polluted environments presenting the particular structure and composition of the

39 weapon burning sites, and submitted to fluctuating water regimes.

40 The contaminated soil at the "Place-à-Gaz" site is regularly subjected to partial water saturation during periods of

41 high precipitation and runoff because of the underlying clayey formation. Moreover, the margin of the site near

42 the oak forest is exposed to natural deposition of litter that provides bioavailable OM. These environmental

43 variations are capable of altering the carriers phases of As and affect bacterial As transformation activities, thereby

44 changing As mobility at the site.

With the aim to better understand the cycle of As in this highly polluted material submitted to environmental changes, an eight-month experiment was performed in a $1 \mathrm{~m}^{3}$ mesocosm filled with contaminated material that was subjected to water saturation episodes and input of bioavailable OM. Monitoring of interstitial water composition at different/various depths in the mesocosm and of leachate (outlet water) provided information on the processes that affect the fate of As and other inorganic contaminants and their transfer towards surrounding environmental compartments (Thouin et al., 2017). After Zn, As was the most mobile inorganic contaminant in the soil water, with concentrations ranging from 20 to $110 \mu \mathrm{M}$. The present study was focused on the evolution of the solid compartment: mineral phases and arsenic-associated microbial parameters. The goal work was to analyze changes in mineral phases and variations in arsenic-associated microbial parameters to increase our understanding 


\section{Materials and methods}

59 Soil was collected at the site named "Place-à-Gaz" (Spincourt Forest, 20 km from Verdun, France) and

60 characterized by Bausinger et al. (2007) and Thouin et al. (2016). It contains slag, coal ash, and residues from

61 ammunition resulting in high concentrations of $\mathrm{Zn}, \mathrm{As}, \mathrm{Cu}$, and $\mathrm{Pb}$ and high organic content $(25.9 \%)$.

62 All soil samples described here come from the instrumented mesocosm experiment presented in Thouin et al.

63 (2017) and shown in supplementary material (SM1). Water and solute fluxes of polluted soil were monitored for

64276 days using the experimental device, which consisted of a closed stainless steel column (1 m in diameter and

$65120 \mathrm{~cm}$ high), filled with $610 \mathrm{~kg}$ of homogenized contaminated soil. After three months of stabilization, the soil

66 was subjected to dry/wet cycles (over a period of about eight (8) months) and to the addition of organic forest litter

67 at the top of the surface soil at the midpoint of the experiment (after four (4) months at T4)(Fig.1.a). The dry period

68 was characterized by a saturation limited to the mesocosm bottom, and by the addition of around $12 \mathrm{~L}$ of Mont

69 Roucous mineral water once a week. The wet period was characterized by the elevation of the water level and by 70 the addition of $6 \mathrm{~L}$ of water every two days. Rainfall was simulated by a sprinkler system. In order to obtain the 71 data previously presented in Thouin et al. (2017), soil solution was sampled at four sampling levels (H1, H2, H3 72 and H4; Fig.1.a) thanks to inert porous probes. H1 and H2 levels were permanently unsaturated, H4 level was 73 permanently saturated and $\mathrm{H} 3$ level was not saturated during dry periods but was saturated during wet periods. 


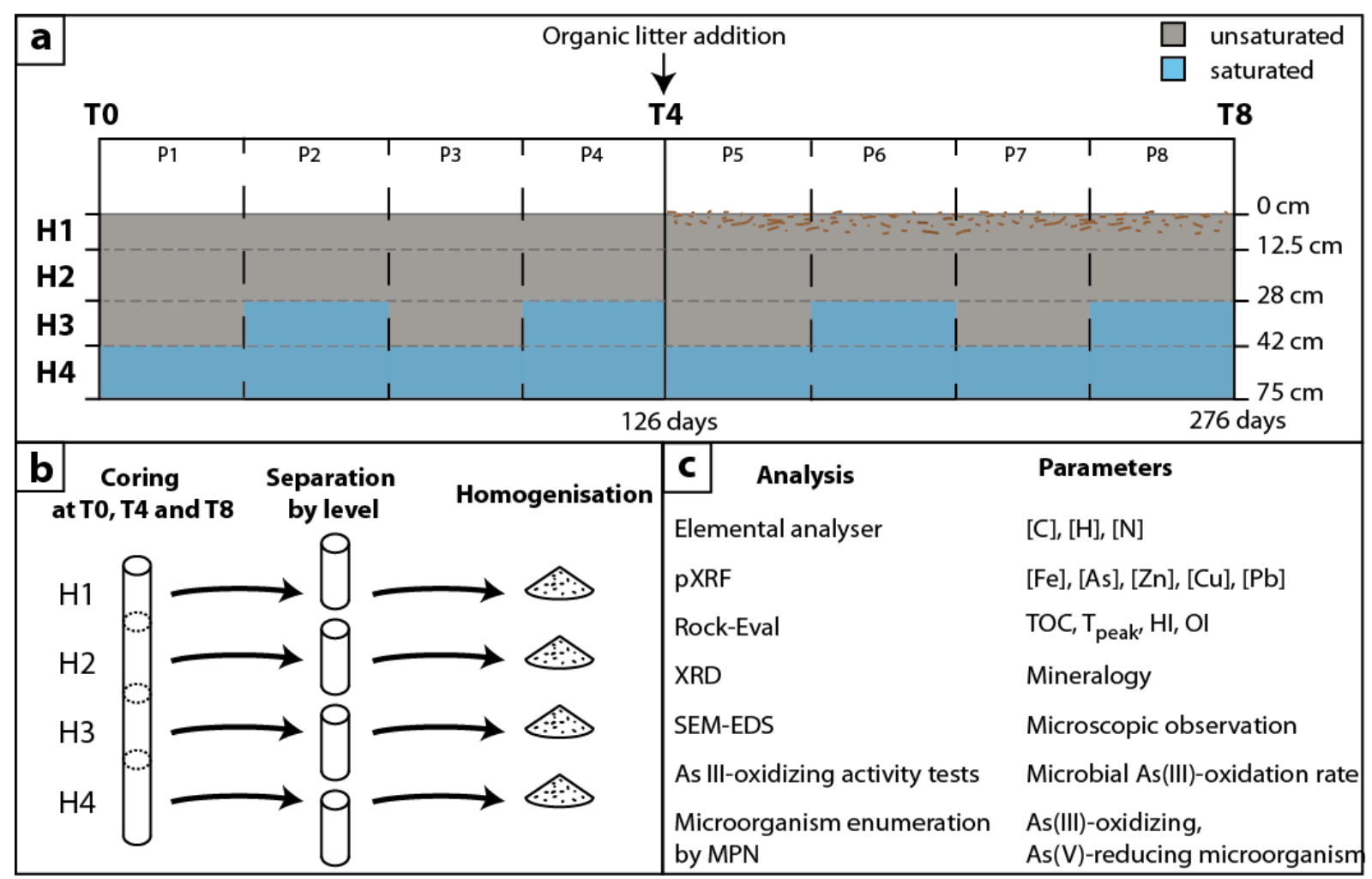

Fig.1. a. Experiment design. P1, P3, P5, P7 and P2, P4, P6, P8 were respectively dry and wet periods. From the beginning of $\mathrm{P} 5$ forest litter was added at the top of the contaminated soil. $\mathrm{H} 4$ was permanently saturated; $\mathrm{H} 2$ and $\mathrm{H} 1$ were never saturated. The H3 level was not saturated in the dry periods and saturated in the wet periods (modified from Thouin et al.,, 2017). b. Coring and sampling of solid material at T0 (at the beginning of the experiment), T4 (after 4 months just before the addition of organic litter) and T8 (at the end of this experiment, i.e. after 8 months). c. Analytical methods and associated parameters performed on each soil sample.

Coring was performed in the mesocosm using $5 \mathrm{~cm}$ diameter stainless steel pipes, at three steps of the experiment: at the beginning (T0), before the addition of fragmented forest litter at the end of month 4 (T4), and at the end of month 8 (T8). After sampling, the pipes were clogged and put back in place in the soil to fill the empty space. Each core was separated into four samples, $\mathrm{H} 1$ at a depth of $0-12.5 \mathrm{~cm}, \mathrm{H} 2$ at $12.5-28 \mathrm{~cm}, \mathrm{H} 3$ at $28-42 \mathrm{~cm}$, and $\mathrm{H} 4$ at 42-75 cm, corresponding to the soil water sampling levels (Fig.1.b). These samples were homogenised and collected in sterile glass jars that were tightly closed and stored at $5^{\circ} \mathrm{C}$.

\section{Analytical techniques}

For chemical analyses, soil samples were dried and ground to $70 \mu \mathrm{m}$. Total carbon, nitrogen, and hydrogen were quantified in powdered samples, using an elemental flash pyrolyser analyser (Flash 2000, Thermo Fischer Scientific). Total organic carbon (TOC), hydrogen index (HI), oxygen index (OI), and maximum temperature

91 of pyrolysable OM ( $\mathrm{T}_{\text {peak }}$ ) were determined by Rock-Eval pyrolysis (Rock-Eval 6 Turbo, Vinci Technologies).

92 The operating principles of this apparatus are described in Lafargue et al. (1998). HI can be used as a maturation 
indicator and is calculated from the amounts of hydrocarbons generated through thermal cracking of nonvolatile organic matter relative to the amount of organic carbon. OI represents the amount of hydrogen relative to the amount of organic carbon present in a sample. It is calculated from the amount of $\mathrm{CO}_{2}$ and $\mathrm{CO}$ released during pyrolysis of the sample. $T_{\text {peak }}$ is the accurate temperature experienced by the sample when producing the maximum amount of hydrocarbons. Total concentrations of $\mathrm{As}, \mathrm{Cu}, \mathrm{Zn}, \mathrm{Pb}$, and Fe were determined using an XL3t800 NITON $^{\odot}$ portable X-ray fluorescence field apparatus (pXRF). The correct correlation of the metal concentrations determined by this technique and by ICP-MS was previously checked in the same soil (Thouin et al., 2016).

The mineralogical composition of the bulk samples was determined by powder X-ray diffraction (XRD). XRD patterns were recorded using an INEL CPS120 diffractometer montage transmission (Debye-Scherrer geometry) equipped with a Co anode (Co K $\left.\alpha_{1}=1.78897 \AA\right)$ and operating at $35 \mathrm{kV}$ and $35 \mathrm{~mA}$. Scans were recorded from $5^{\circ}$ to $90^{\circ}(2 \theta)$ with angular steps of $0.03^{\circ}$ and a total acquisition time of $210 \mathrm{~min}$.

Scanning electron microscopy (SEM) and energy dispersive X-ray spectroscopy (EDS) were used to study the structural evolution of As and metal carrier phases during the experiment and to identify possible new precipitated phases. The samples were air dried, deposited on a carbon adhesive and directly analyzed. All types of grains were investigated for morphological observation and elemental distribution. SEM was performed on a TM 3000 (Hitachi) operating at $15 \mathrm{kV}$ accelerating voltage. The SEM was coupled to a Swift ED $3000 \mathrm{X}$-Stream module (Hitachi). The acquisition time of EDS point analyses was 300 seconds.

\section{As(III)-oxidizing activity tests and bacterial enumeration}

Soil samples were incubated at $25^{\circ} \mathrm{C}$ for $72 \mathrm{~h}$ before starting the As(III)-oxidizing activity tests and the enumeration of $\mathrm{As}(\mathrm{III})$-oxidizing and $\mathrm{As}(\mathrm{V})$-reducing microorganisms. It was previously shown that this step allows restoring As-related microbial activities in soil and sediment samples that were stored at $5^{\circ} \mathrm{C}$ (Lescure et al., 2013; 2016). The As(III)-oxidizing tests were performed in triplicate in $250 \mathrm{~mL}$ Erlenmeyer flasks filled with $100 \mathrm{~mL}$ of CAsO1 medium (Bachate et al., 2002) supplemented with $1 \mathrm{mM} \mathrm{As(III)} \mathrm{and} \mathrm{inoculated} \mathrm{with} \mathrm{a} \mathrm{mass} \mathrm{of}$ material equivalent to $0.2 \mathrm{~g}$ of dry weight. Flasks were plugged with cotton to retain oxidizing conditions and were incubated at $25^{\circ}$ under agitation $(100 \mathrm{rpm})$. Samples were filtrated $(0.45 \mu \mathrm{m})$ and stored at $-20^{\circ} \mathrm{C}$ until analysis. As(III) and As(V) were separated using the PDC/MIBK method (Battaglia-Brunet et al., 2002). Separated neutral fraction, attributed to $\operatorname{As}(\mathrm{V})$ was then quantified by Flame Atomic Absorption Spectrometry (FAAS) (Varian, Palo 

versus time line, during the reaction.

123 The evolution of the concentration in As(III)-oxidizing and As(V)-reducing microorganisms was followed using

124 the Most Probable Number method (MPN). The method for As(III)-oxidizing microorganisms is detailed in 125 Thouin et al. (2016). For As(V)-reducing microorganisms (method adapted from Kuai et al., 2001), fresh soil 126 (equivalent to $0.2 \mathrm{~g}$ dry soil) was placed in a sterile, glass Erlenmeyer flask with $10 \mathrm{~mL}$ of sterile physiological 127 saline (9 g.L $\mathrm{L}^{-1} \mathrm{NaCl}$ in demineralized water), shaken for $30 \mathrm{~min}$ at $25^{\circ} \mathrm{C}$, then sonicated $2 \times 20 \mathrm{~s}$ at $45 \mathrm{kHz}$.

128 Triplicate suspensions were prepared for each sample. Soil suspensions were diluted in sterile physiological saline 129 solution to a dilution of $10^{-6}$. CAsO1 basal mineral medium (Battaglia-Brunet et al., 2002) was complemented with

$13020 \mathrm{mM}$ lactic acid and As(V) (100 mg.L $\left.\mathrm{L}^{-1}\right)$. The medium was distributed over Microtest TM Tissue culture plates 131 (96 wells), $250 \mu \mathrm{L}$ per well. Each well was inoculated with $25 \mu \mathrm{L}$ of diluted soil suspension. Five wells were 132 inoculated with each dilution. Culture plates were incubated at $25^{\circ} \mathrm{C}$ for 10 days in anaerobic jars with Anaerocult 133 packs (Merck). The presence of As(III) formed in the wells during incubation was revealed by the formation of 134 As(III)-PyrrolidineDithioCarbamate (PDC), an insoluble white complex: $80 \mu \mathrm{L}$ of $0.1 \mathrm{M}$ acetate buffer (pH 5) and $13540 \mu \mathrm{L}$ PDC solution $\left(5 \mathrm{~g} . \mathrm{L}^{-1}\right)$ were added to each well. The number of positive wells for each dilution was 136 determined, and the most probable number of $\mathrm{As}(\mathrm{V})$-reducing microorganisms was given by the Mc Grady table 137 for five tubes.

\section{Statistical analyses}

139 Statistical tests were carried out using R 3.2.4 (www.r-project.org). Pearson correlations were calculated with the 140 four soil samples at three time steps i.e. 12 observations. Principal component analysis (PCA) was performed on 141 biogeochemical parameters on the same observations.

\section{Results and discussion}

\subsection{Stability of As bearing mineral phases}

\section{Relationship between As and metals}

145 As and metal concentrations measured/quantified by the pXRF method were high in all soil samples, in the 146 following decreasing order $\mathrm{As}>\mathrm{Fe}>\mathrm{Zn}>\mathrm{Cu}>\mathrm{Pb}(\mathrm{SM} 2)$. Arsenic concentrations ranged from 102,380 to 150,360 147 mg.kg-1 $\mathrm{Zn}$ concentrations from 70,040 to $107,400 \mathrm{mg} \cdot \mathrm{kg}^{-1}, \mathrm{Cu}$ concentrations from 13,450 to $20,790 \mathrm{mg} . \mathrm{kg}^{-1}$, 148 and $\mathrm{Pb}$ concentrations from 3,490 to 6,030 $\mathrm{mg}^{\mathrm{kg}} \mathrm{kg}^{-1}$ (SM2). These inorganic contaminant concentrations were very 149 elevated and in the same range as those measured in other soil samples from the same site (Bausinger et al., 2007; 
150 Thouin et al., 2016). Concentration variations were difficult to detect with depth and time because of the high

151 heterogeneity of the soil. However, at the end of the experiment (T8), metal(loid) concentrations seemed to be

152 distributed in a pattern showing higher values at the bottom of the mesocosm (H4) (Fig.2; SM2). Moreover, As

153 and metals were less concentrated at the surface after eight (8) months than at the beginning of the experiment

154 (Fig.2; SM2). These observations may be the result of the downward vertical transport of metals within the

155 mesocosm and their accumulation in the saturated soil. Monitoring of metal(oid) concentrations in interstitial water

156 (Thouin et al., 2017) showed that As was immobilized in the bottom level H4 of the mesocosm as its concentration

157 values decreased from $60-80 \mu \mathrm{M}$ in unsaturated soil to $40 \mu \mathrm{M}$ in the saturated zone. However, this phenomenon

158 was not observed with other inorganic contaminants. Moreover, the amounts of As released from the liquid phase

159 in the saturated parts are too low to explain the increase of about $40,000 \mathrm{mg} \cdot \mathrm{kg}^{-1}$ at the bottom of the mesocosm.

160 It seems more likely that these results highlight the downward particular transport of contaminant-bearing fine

161 particles during the experiment, even if these results are not sufficient to confirm this hypothesis.

162 Arsenic concentration was significantly correlated with that of metals, as shown by Pearson indices $>0.80$ (Fig.2),

163 with the exception of Fe concentration which was not correlated with any other metal(loid)s. These results suggest

164 that $\mathrm{As}, \mathrm{Zn}, \mathrm{Cu}$, and $\mathrm{Pb}$ were mainly linked to the same solid phase, as shown in previous characterizations of the

165 polluted material (Thouin et al., 2016), indicating that the principal As carrier was an amorphous phase containing

166 high concentrations of metals. 


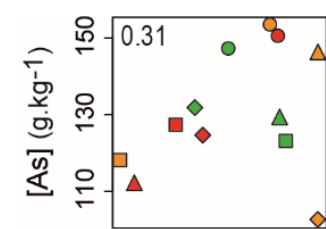

\section{Sampling times \\ $\square \square \square$}

Sampling levels
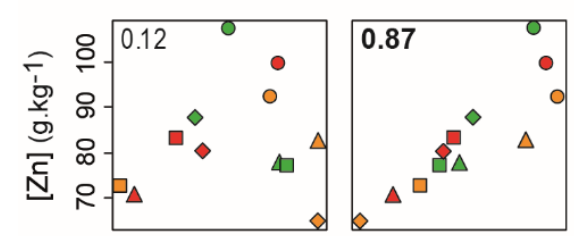

$\triangle \mathrm{H} 1$

$\square \mathrm{H} 2$

$\diamond \mathrm{H} 3$

$\mathrm{OH} 4$
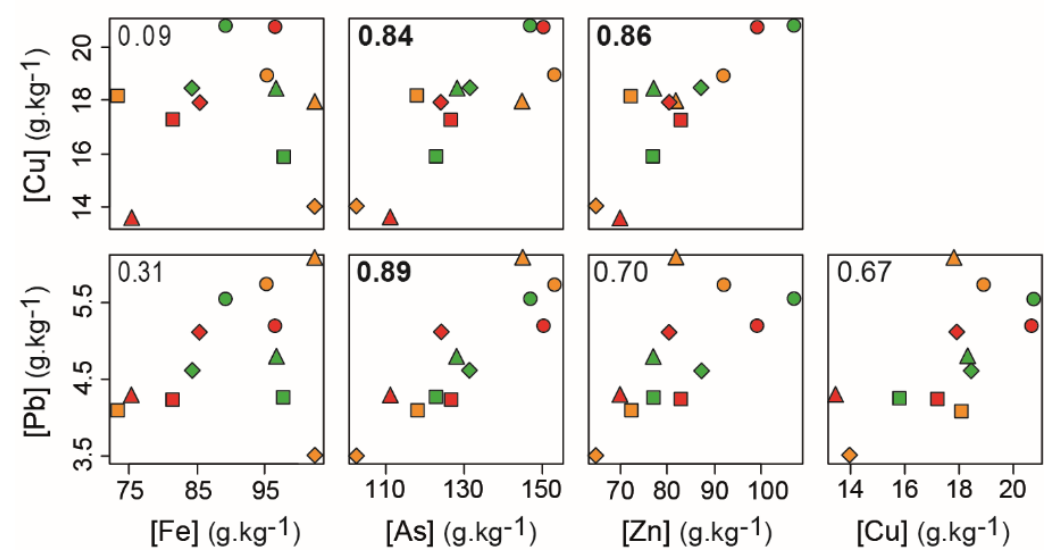

[As] $\left(\mathrm{g} \cdot \mathrm{kg}^{-1}\right)$

[Zn] (g.kg-1)

[Cu] $\left(\mathrm{g}^{\mathrm{kg}} \mathrm{g}^{-1}\right)$

168 Fig.2. Scatterplot matrix of metal(loid) concentration. Pearson correlation coefficient of variables is specified in 169 the upper-left corner of each panel (highest correlations are indicated in bold characters).

\section{Stability of amorphous phases}

171 Morphological evolution of amorphous phases was observed by SEM in various samples, so as to compare their

172 stability at different times and under different environmental conditions. In the unsaturated levels, amorphous

173 phases did not show evidence of weathering all along the experiment. Figure 2 shows the textural evolution of the

174 vitrified amorphous phases in the soil level that was permanently water saturated. At the beginning of the

175 experiment (Fig.3 (a)), this phase was characterized by a smooth texture with micro-cracks, similar to the

176 morphology previously observed in samples from the site and attributed to the thermal process used to destroy the

177 weapons (Thouin et al., 2016). After four (4) months of the mesocosm experiment, the surface of the amorphous

178 phases had changed and taken on a rough texture (Fig.3 (b)). Edges of the cracks were altered and new fissure

179 networks grew from the previous micro-cracks. At the end of the experiment, after 276 days of water saturation,

180 the fissure networks covered the entire surface of the amorphous phases, which had become highly irregular (Fig.3

181 (c)). Similar observations have been made during the alteration of a partially vitrified metallurgical waste (Seignez

182 et al., 2007). This morphological evolution may be consistent with dissolution of amorphous phase surfaces in the

183 saturated soil, which should be accompanied by the release of $\mathrm{As}, \mathrm{Zn}, \mathrm{Cu}, \mathrm{Pb}$. However, metal(oid)s behaved 
184 differently with high As and $\mathrm{Zn}$ concentrations in solution, whereas $\mathrm{Cu}, \mathrm{Pb}$ and $\mathrm{Fe}$ were not very mobile (Thouin 185 et al., 2017).

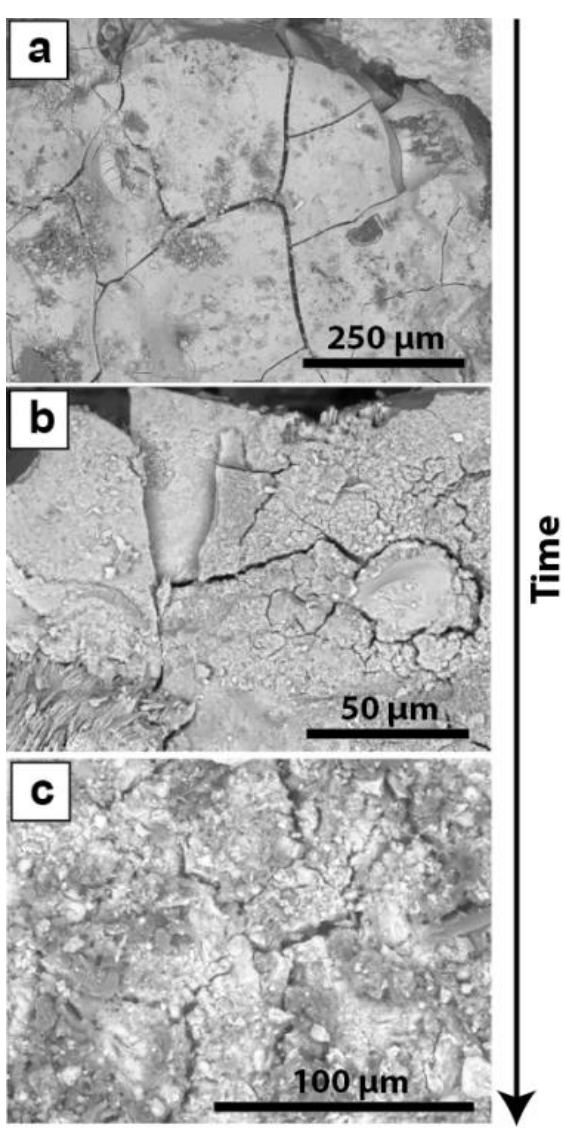

187 Fig.3. Backscattered electron images of amorphous phases in the saturated soil. (a), (b) and (c) illustration of three amorphous phases sampled in the $\mathrm{H} 4$ level at T0, $\mathrm{T} 4$ and $\mathrm{T} 8$ respectively.

Elemental composition of altered amorphous phases was investigated using SEM-EDS analyses (SM3). The elemental maps of $\mathrm{Fe}, \mathrm{Zn}, \mathrm{As}, \mathrm{Pb}$ and $\mathrm{Cu}$ on amorphous phases presenting a partially altered surface showed a different distribution between Fe and $\mathrm{Zn}$. In this study zone Fe content was lower in the smooth amorphous phases than in the rough surface. An alteration study of partially vitrified metallurgical waste composed primarily of an iron-silica-lime glass matrix showed that altered glass is characterized by relative enrichments of iron induced by

194 high calcium depletion (Seignez et al., 2007). Here the results were similar, with higher iron concentrations in altered material even though this amorphous material does not have the same chemical composition (no silicium).

196 Other studies showed that under oxidizing conditions, iron mobilized during dissolution of the vitrified material precipitated on the surface of the altered zone (Deneele 2002; Ettler et al., 2004). Our results can be explained by

198 the precipitation of amorphous and poorly crystallized ferric oxides and/or hydrous ferric oxides (HFO) in the proximity of the amorphous phase, which can bind a portion of As and metals. This hypothesis is consistent with the low concentrations of mobile Fe $(<40 \mu \mathrm{M}$ throughout the experiment, Thouin et al., 2017). The precipitation 
201 of iron oxy-hydroxide permits the sorption of $\mathrm{Cu}$ and $\mathrm{Pb}$ (Swallow et al., 1980) and may also explain the low mobility of these elements. Moreover, the high adsorption of $\mathrm{As}(\mathrm{V})$ by amorphous HFO is a well-known 203 phenomenon (Dixit and Hering 2003). Thus, precipitation of HFO resulting from the dissolution of amorphous 204 phases in the water-saturated material may be one of the phenomena inducing the immobilization of As(V) that 205 was observed in this specific environment of the mesocosm. The $\mathrm{Zn}$ depletion observed in the surface of the altered zone (SM3) seems to show the easier mobilization and the low affinity to HFO of Zn. These assumptions are consistent with the important $\mathrm{Zn}$ concentration in the soil solution, induced by favorable $\mathrm{pH}$ conditions (pH range of 5-6; Thouin et al., 2017), during the experiment.

\section{Evolution of the mineralogical association}

210 XRD analysis of soil samples from different depths was used to investigate the mineralogical evolution of the 211 polluted material during the experiment (Fig.4). First, the high background of X-ray diffractograms confirmed the 212 abundance of amorphous phases in the soil. Quartz and potassium and sodium feldspars were identified in each 213 sample with a relative peak intensity that evolved slightly over time and depth. These silicates, which had already 214 been observed in samples from the polluted site (Thouin et al., 2016), were attributed to the substrate, i.e. the 215 clayey Woëvre formation.

216 Magnetite $\left(\mathrm{Fe}_{3} \mathrm{O}_{4}\right)$ and franklinite $\left(\mathrm{ZnFe}_{2} \mathrm{O}_{4}\right)$ were detected in most samples. Magnetite and franklinite exhibit a 217 spinel structure with similar lattice parameters that result in an overlapping of their corresponding XRD peaks, so 218 it is difficult to ascertain the presence of franklinite with XRD spectra. However, the $\mathrm{Zn}$ concentration in solids 219 and the common occurrence of the magnetite-franklinite mineral association in metallurgical furnace wastes 220 (Pisciella et al., 2001; Juillot et al., 2003; Dutra et al., 2006; Puziewicz et al., 2007; Seignez et al., 2007; Vereš 221 2014) and in vitrified products of electrostatic precipitator ash from municipal solid wastes (Le Forestier and 222 Libourel 2008) suggest that magnetite-franklinite solid solutions are present as a result of the thermal destruction 223 process. The presence of zincite in site soil samples (Thouin et al., 2016) and in metallurgical wastes, together 224 with magnetite and franklinite (Dutra et al., 2006; Puziewicz et al., 2007; Vereš 2014), confirm the inherited character of these minerals in this context. Although not detected by XRD in the mesocosm samples, zincite, as 226 well as magnetite and franklinite, were most probably present but in insufficient amounts for appropriate detection 227 due to soil heterogeneity. No significant effect of dry/wet cycles or the addition of OM on the stability of these Fe 228 and $\mathrm{Zn}$ minerals was detected. 


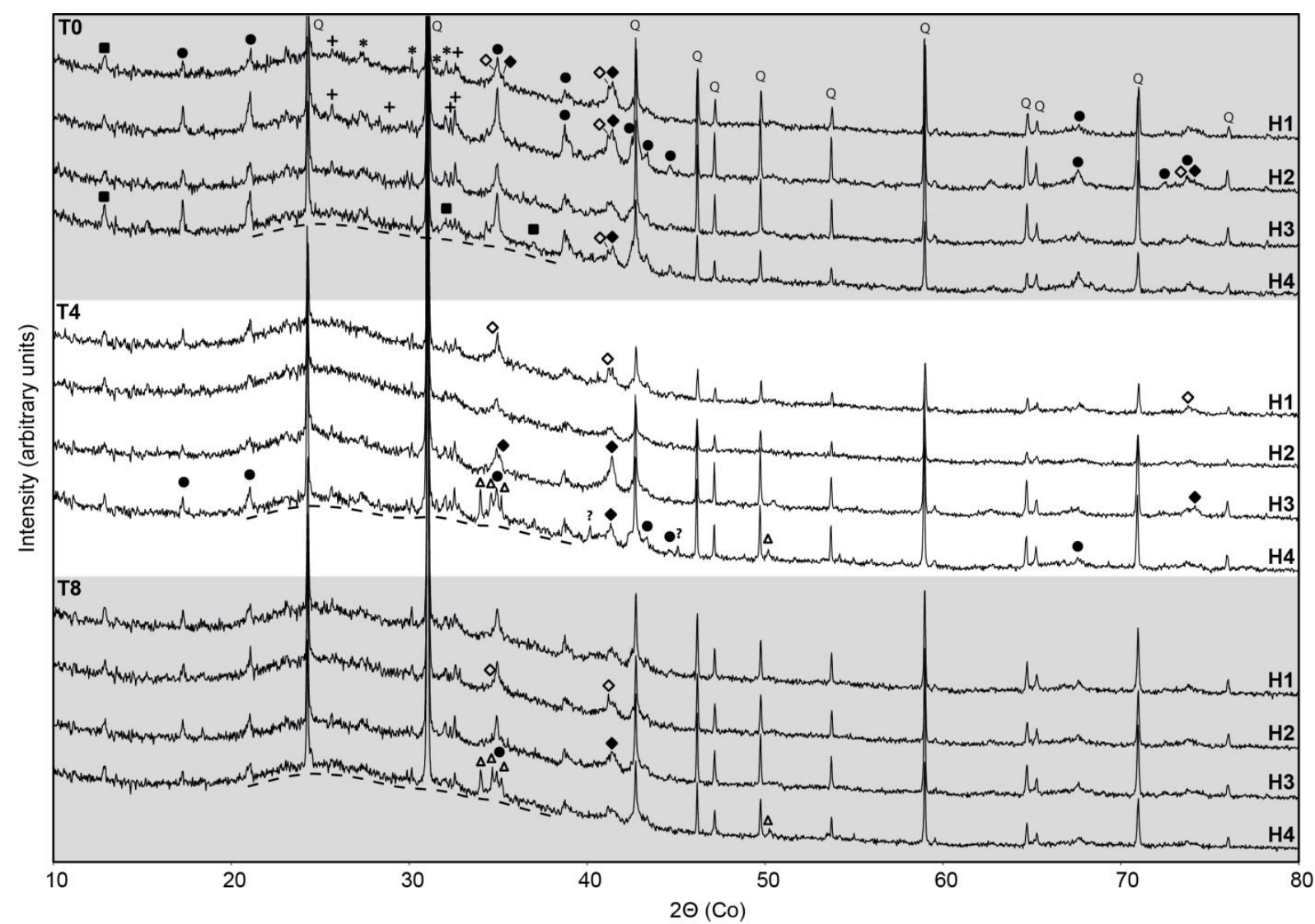

230 Fig.4. X-ray diffractograms of bulk soil samples. Q: quartz (ICDD-1045); *: sodium feldspar (ICDD 19-1184); 231 +: potassium feldspar (ICDD 31-0966); $\bullet$ :adamite (ICDD 39-1354); $\mathbf{\square}$ : Na-Pharmacosiderite (ICDD 38-0388); $232 \diamond$ : magnetite (ICDD 19-0629); $\diamond$ : franklinite (ICDD 22-1012); $\Delta$ : mimetite (ICDD 19-0683); and ?: unidentified 233 mineral.

$234 \mathrm{The} \mathrm{Zn}, \mathrm{Cu}$, and $\mathrm{Fe}$ arsenates previously observed in this soil (Thouin et al., 2016), adamite $\left(\mathrm{Zn}_{2} \mathrm{AsO}_{4}(\mathrm{OH})\right.$ ), 235 olivenite $\left(\mathrm{Cu}_{2} \mathrm{AsO}_{4}(\mathrm{OH})\right)$, and pharmacosiderite $\left((\mathrm{K}, \mathrm{Na}, \mathrm{Ba}) \mathrm{Fe}_{4}\left(\mathrm{AsO}_{4}\right)_{3}(\mathrm{OH})_{5} 5 \mathrm{H}_{2} \mathrm{O}\right)$ were again identified in all 236 samples (Fig.4). Adamite and olivenite are characterized by the same structure so they have similar XRD patterns, 237 but SEM-EDS showed that crystals were mostly a solid solution of adamite and olivenite (SM4.a). Indeed, 238 adamite-olivenite crystals were easily recognized because of their prismatic and acicular texture, and the ability to 239 form large crystals that may grow on grain surfaces. Pharmacosiderite with a cubic structure was also observed 240 (SM4.b). No evidence of weathering was observed on these arsenate minerals, which were present all along the 241 soil profile.

242 Mimetite $\left(\mathrm{Pb}_{5}\left(\mathrm{AsO}_{4}\right)_{3} \mathrm{Cl}\right)$, a lead arsenate chloride, was detected exclusively in the water-saturated $\mathrm{H} 4$ level at $\mathrm{T} 4$ 243 and T8 (Fig.4). Mimetite precipitation was proposed to be part of a soil treatment technology allowing the removal 244 of arsenate ions from solution (Twidwell et al., 1994 ; Bajda et al., 2006). Indeed, mimetite precipitates under conditions of low $\mathrm{Pb}$ and arsenate concentrations and has a stability domain that covers the $\mathrm{pH}$ range of natural 
waters (Magalhães and Silva 2003; Bajda 2010). Arsenate and chloride ions, which were present in high concentrations in interstitial water throughout the experiment, and the pH range of 5.5-6.0 (Thouin et al., 2017) were optimal for mimetite precipitation. The factor that limited mimetite precipitation in the soil was the low amount of dissolved $\mathrm{Pb}$ concentration. Mimetite precipitation in the saturated part of the soil means that $\mathrm{Pb}$ was previously released into solution under these conditions; this confirms the hypothesis of progressive dissolution of metal-bearing amorphous phases throughout the experiment. Mimetite was not observed with SEM, but micrometric grains with high lead and other metal concentrations were observed in the saturated depth level (SM4.c). This observation confirms that lead was released and then re-precipitated. Mimetite precipitation, promoted by soil water saturation, was probably one of the phenomena that caused the previously observed immobilization of $\mathrm{Pb}$ and $\mathrm{As}(\mathrm{V})$. Due to mimetite's broad $\mathrm{pH}$ stability range (down to $\mathrm{pH}=2$ ), this mineral represents a durable trap for $\mathrm{As}$ and $\mathrm{Pb}$. However, the very low dissolved $\mathrm{Pb}$ concentration limited mimetite precipitation and relatively high amounts of As remained in solution.

\subsection{Modification of the soil organic matter}

Characterization of soil OM present in the mesocosm was performed using an elemental flash pyrolyser analyser and Rock-Eval pyrolysis. Results are represented in table 1. Total carbon (C) ranged from 14.7 to $27.8 \%$, and total hydrogen from 1.6 to $2.4 \%$ in the mesocosm soil. The $\mathrm{N}$ content of soil ranged from 0.3 to $0.8 \%$. TOC ranged between 14.1 and $25.3 \%$. HI results were low for all mesocosm samples ( $<0.18 \mathrm{mg} \mathrm{HC} . \mathrm{g}^{-1}$ TOC) except

$264 \mathrm{~T}_{\text {peak }}$ values were higher than $440{ }^{\circ} \mathrm{C}$, and were higher than $500{ }^{\circ} \mathrm{C}$ for two samples $(\mathrm{H} 3-\mathrm{T} 4$ and $\mathrm{H} 4-\mathrm{T} 8)$. The 265 high organic carbon content together with the $\mathrm{HI}$ and OI values are quite different from those expected in soil OM 266 (Disnar et al., 2003), but instead show chemical signatures of charcoals (Wolf et al., 2013; Saenger et al., 2015).

267 Previous studies suggest that physical and chemical charcoal properties depend on the temperature of the fire 268 (Schneider et al., 2010; Wolf et al., 2013). Charcoal formation begins with the loss of easily oxidizable OM (such as aliphatic and carboxylic compounds), thus with increasing temperature organic compounds progressively aromatize. High temperature combustion $\left(>700^{\circ} \mathrm{C}\right)$ may cause complete carbonization of $\mathrm{OM}$ and may form polyaromatic crystallites or graphite-like structures (Keiluweit et al., 2010). This restructuring of OM is expressed

272 by an increase in TOC and a decrease in OI and HI. Wolf et al., (2013) studied the relationship between charcoal 273 signatures and burning conditions. According to their data, our OM signature (HI/OI, $\mathrm{T}_{\text {peak }}$ ) would correspond to 274 a fire temperature ranging between 300 and $400{ }^{\circ} \mathrm{C}$. However, this temperature seems to be relatively low for 
275 melting metals $(\mathrm{Fe}, \mathrm{Cu}, \mathrm{Zn}, \mathrm{Pb})$ from shell parts, thus to form the amorphous phases. Wood was placed on top of 276 the shell dumps during destruction. The temperature was probably higher in the center of the fire, thus explaining 277 the difference between the fire temperature signal of charcoal and the total range of temperatures reached during 278 combustion.

279 Table 1 Parameters related to OM

\begin{tabular}{|c|c|c|c|c|c|c|c|c|c|c|}
\hline & Time & $\mathrm{C}^{\mathrm{a}}$ & $\mathrm{H}^{\mathrm{a}}$ & $\mathrm{N}^{\mathrm{a}}$ & $\mathrm{C} / \mathrm{N}^{\mathrm{a}}$ & TOC $^{\mathrm{b}}$ & $\mathrm{T}_{\text {peak }}{ }^{\mathrm{b}}$ & $\mathrm{HI}^{\mathrm{b}}$ & $\mathrm{OI}^{\mathrm{b}}$ & $\mathrm{HI} / \mathrm{OI}^{\mathrm{b}}$ \\
\hline & & $\%$ & $\%$ & $\%$ & & $\%$ & ${ }^{\circ} \mathrm{C}$ & $\begin{array}{l}\text { mg HC. } \\
\mathrm{g}^{-1} \text { TOC }\end{array}$ & $\begin{array}{c}\mathrm{mg} \mathrm{O}_{2} \\
\mathrm{~g}^{-1} \text { TOC }\end{array}$ & \\
\hline H1 & \multirow{4}{*}{ T0 } & 21.1 & 1.8 & 0.6 & 36.3 & 16.1 & 441 & 13 & 161 & 0.08 \\
\hline $\mathrm{H} 2$ & & 23.8 & 2.1 & 0.7 & 36.2 & 24.9 & 446 & 11 & 125 & 0.09 \\
\hline H3 & & 25.9 & 2.3 & 0.7 & 36.6 & 18.5 & 443 & 17 & 161 & 0.11 \\
\hline $\mathrm{H} 4$ & & 27.8 & 2.4 & 0.8 & 37.0 & 14.6 & 445 & 15 & 200 & 0.08 \\
\hline H1 & \multirow{4}{*}{$\mathrm{T} 4$} & 27.1 & 2.4 & 0.7 & 38.1 & 15.3 & 446 & 15 & 184 & 0.08 \\
\hline $\mathrm{H} 2$ & & 25.9 & 2.2 & 0.6 & 40.5 & 18.3 & 452 & 16 & 147 & 0.11 \\
\hline $\mathrm{H} 3$ & & 14.7 & 1.5 & 0.3 & 53.5 & 14.1 & 542 & 18 & 157 & 0.11 \\
\hline $\mathrm{H} 4$ & & 15.1 & 1.6 & 0.3 & 45.8 & 19.4 & 440 & 14 & 147 & 0.10 \\
\hline H1 & \multirow{4}{*}{$\mathrm{T} 8$} & 27.8 & 2.4 & 0.8 & 37.0 & 25.3 & 439 & 37 & 169 & 0.22 \\
\hline $\mathrm{H} 2$ & & 22.6 & 1.8 & 0.4 & 53.2 & 23.2 & 445 & 16 & 151 & 0.11 \\
\hline $\mathrm{H} 3$ & & 22.8 & 1.7 & 0.5 & 49.5 & 22.8 & 446 & 18 & 150 & 0.12 \\
\hline $\mathrm{H} 4$ & & 17.1 & 1.6 & 0.4 & 46.2 & 17.5 & 559 & 18 & 154 & 0.12 \\
\hline Litter & & 38.5 & 4.7 & 1.8 & 21.4 & 30.5 & 369 & 268 & 205 & 1.31 \\
\hline
\end{tabular}

280 a : Flash pyrolyser analyser; b : Rock-Eval 6

281 The forest litter added at T4 had a very different signal from that of the soil. It has higher organic carbon (30.5\%) 282 and nitrogen $(1.8 \%)$ concentrations, higher HI (268 mg HC. $\mathrm{g}^{-1}$ TOC) and OI (205 mg O $\left.\mathrm{O}_{2} \mathrm{~g}^{-1} \mathrm{TOC}\right)$ values, and a 283 lower $\mathrm{T}_{\text {peak }}\left(369^{\circ} \mathrm{C}\right)$. Disnar et al. (2003) determined that fresh or fragmented litter normally has high TOC values $284(10-40 \%)$ and HI values higher than $300 \mathrm{mg} \mathrm{HC} \cdot \mathrm{g}^{-1} \mathrm{TOC}$. The $\mathrm{T}_{\text {peak }}$ of $360-370{ }^{\circ} \mathrm{C}$ is mostly attributed to cellulose 285 and/or lignin, two major components of woody tissues frequently observed in litters. These results confirmed the 286 immature nature of the organic litter added to the top soil of the mesocosm.

287 The intrinsic OM of the "Place-à-Gaz" soil, with a high C/N and low HI/OI ratio has characteristics of a barely 288 biodegradable material (Tab.1 and SM5). However, the addition of fragmented forest litter enhanced the proportion 289 of biodegradable OM in the top soil. The effect of forest litter was visible on surface soil sample H1 - T8, which had a higher organic carbon content $(25.3 \%)$ and a higher HI/OI ratio (0.22; Tab.1 and SM5), but not a higher 
291 C/N ratio. Addition of organic litter increased the carbon mineralization rate in the mesocosm (Thouin et al., 2017),

292 as a result, it was supposed that the addition of litter increased microbial activity.

293

294

295

296

297

298

299

300

301

302

303

304

305

306

\subsection{Biogeochemistry of arsenic}

\section{Microbial arsenic transformation}

As(III)-oxidizing activity tests were used to evaluate the potential for microbial As(III) oxidation during the experiment (Fig. 5). These global activity tests integrate the diversity and abundance of microflora and environmental soil conditions (Lescure et al., 2016). With samples collected at T0, As(III) oxidation started after 70 and 90 hours of lapsed time at all levels. The results of microbial As(III) oxidation activity tests at T0 were consistent with results previously obtained with soil sampled from the most polluted zone of the "Place-à-Gaz" site (Thouin et al., 2016), with identical latency of about $100 \mathrm{~h}$. Here, the lapsed time decreased progressively during the mesocosm experiment, particularly in the water-saturated levels. At T8, the As(III) oxidation kinetics of each sample were well separated temporally, with complete As(III) oxidation achieved in time periods that increased as follows: $\mathrm{H} 4<\mathrm{H} 3<\mathrm{H} 2<\mathrm{H} 1$. The rate of microbial As(III) oxidation was consistently higher in saturated or alternatively saturated/unsaturated levels $\mathrm{H} 4$ and $\mathrm{H} 3$ than in unsaturated levels $\mathrm{H} 1$ and $\mathrm{H} 2$ (except for H3 T0) (Fig.5.b). The rate of microbial As(III) oxidation decreased over time, mostly in H1 and H4, whose As(V) values decrease from 1.3 and $2.2 \mathrm{mg}$ of $\mathrm{As}(\mathrm{V}) \cdot \mathrm{mL}^{-1} \cdot \mathrm{h}^{-1}$ at $\mathrm{T} 0$ to 0.8 and $1.3 \mathrm{mg}$ of $\mathrm{As}(\mathrm{V}) \cdot \mathrm{mL}^{-1} \cdot \mathrm{h}^{-1}$ at $\mathrm{T} 8$. 
a
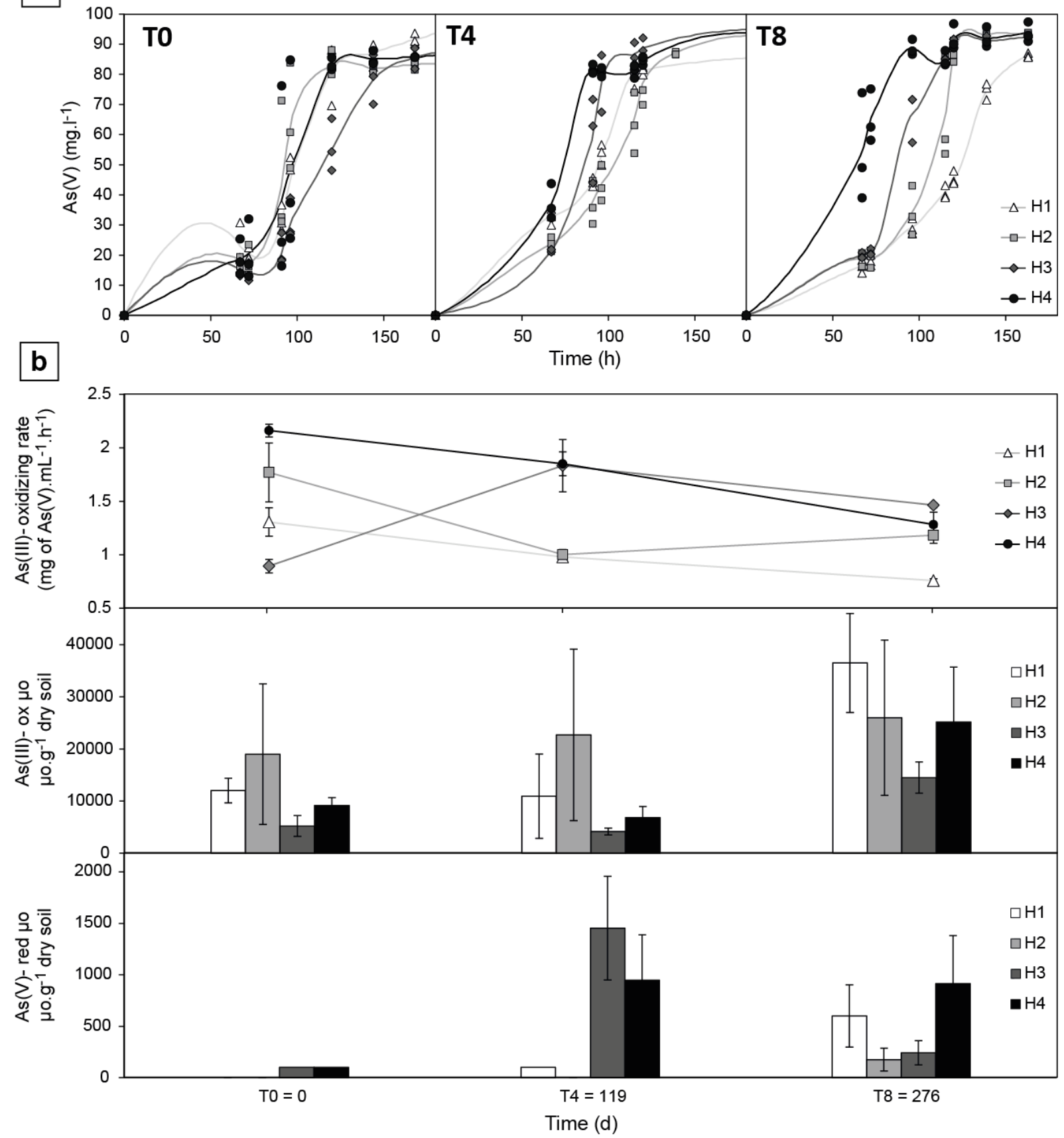

Fig.5. Microbial As(III)-oxidizing and As(V)-reducing activities. a: Evolution of $\mathrm{As}(\mathrm{V})$ concentration during the As(III)-oxidizing activity test for the four soil samples at T0, T4 and T8. b: Plot of As(III) oxidation rates

311 corresponding to the activity tests in "a". Concentration of As(III)-oxidizing and As(V)-reducing microorganisms 312 evaluated by MPN. Errors bars represent the standard deviation of the mean of three replicates for the four soil 313 samples. For As(V)-reducing microorganisms a lack of value means that results from the two or three replicates 314 were $<50 \mu \mathrm{o}_{\mathrm{g}} \mathrm{g}^{-1}$ dry soil. (ox: oxidizing; red: reducing; $\mu \mathrm{o}$ : microorganisms).

315 The evolution of abundance of As(III)-oxidizing and As(V)-reducing microorganisms was followed by MPN

316 (Fig.5.b). Between T0 and T4, As(III)-oxidizing microorganism concentrations were stable with higher values in $317 \mathrm{H} 2$ and lower in $\mathrm{H} 3$. 
318 After the addition of fragmented forest litter, the concentration of As(III)-oxidizing microorganisms increased in 319 all levels, and particularly in H1. As(V)-reducing microorganisms abundance that could be estimated by the 320 selected MPN method were significantly lower than As(III)-oxidizing microorganisms (one order of magnitude 321 less). At T0, less than $100 \mathrm{As}(\mathrm{V})$-reducing microorganisms per gram of dry soil were observed. After four (4) 322 months of the experiment, As(V)-reducing microorganism concentrations increased in the saturated and 323 alternatively saturated/unsaturated levels. At T8, the concentration of As(V)-reducing microorganisms increased 324 in $\mathrm{H} 1$ and $\mathrm{H} 2$, decreased in $\mathrm{H} 3$, and remained constant in H4. Thus, both water saturation (for H3 and H4) and 325 OM supply (for H1 and H2) seemed to promote the growth of As(V)-reducing micro-organisms.

The impact of water saturation levels and redox oscillation on As solubility has been described in many studies 328 (Kumpiene et al., 2009 ; Weber et al., 2010 ; Parsons et al., 2013 ; Couture et al., 2015) where it was shown that soil saturation increased As solubility by the way of reduction of Fe oxides together with more efficient microbial reduction of As(V). Increased As(III) concentration in soil solution previously observed in the saturated level $\mathrm{H} 4$ of the mesocosm (Thouin et al., 2017) could be related to increased As(V)-reducing microorganism concentrations in the saturated zones. The stimulation of microbial As(V)-reducing activity induced by soil saturation may have negatively impacted the overall As(III) oxidation rate in water-saturated levels, but could not explain a decreased As(III) oxidation rate in unsaturated levels H1 and H2 (Fig.5.a T8).

OM may also affect microbial As(III) oxidizing activity. For example, high concentrations of organic substrates may inhibit this activity (Challan-Belval et al., 2009 ; Bachate et al., 2012 ; Lescure et al., 2016) and may also stimulate aerobic As(V)-reducing activity of soil microorganisms (Yamamura et al., 2009). The As(III) oxidation rate results from the overall activity of all microorganisms involved in As speciation, because microbial As(III) oxidation and $\mathrm{As}(\mathrm{V})$ reduction can occur simultaneously, even under aerobic conditions.

340 To describe more precisely the impact of the addition of litter on the available microbial parameters, a principal 341 components analysis (PCA) was built (Fig.6), including variables that describe OM quantities and qualities (TOC, 342 DOC, HI/OI, C/N), microbial As transformation parameters (As(III)-oxidation rate, concentrations of As(III)343 oxidizing microorganisms and As(V)-reducing microorganisms), and the variables related to the water phase of 344 the mesocosm, given in Thouin et al., (2017): As speciation and mobility in the interstitial water ([As], [As(III)], $345[\mathrm{As}(\mathrm{V})])$, and physicochemical parameters of water ( $\mathrm{pH}, \mathrm{Eh})$. 

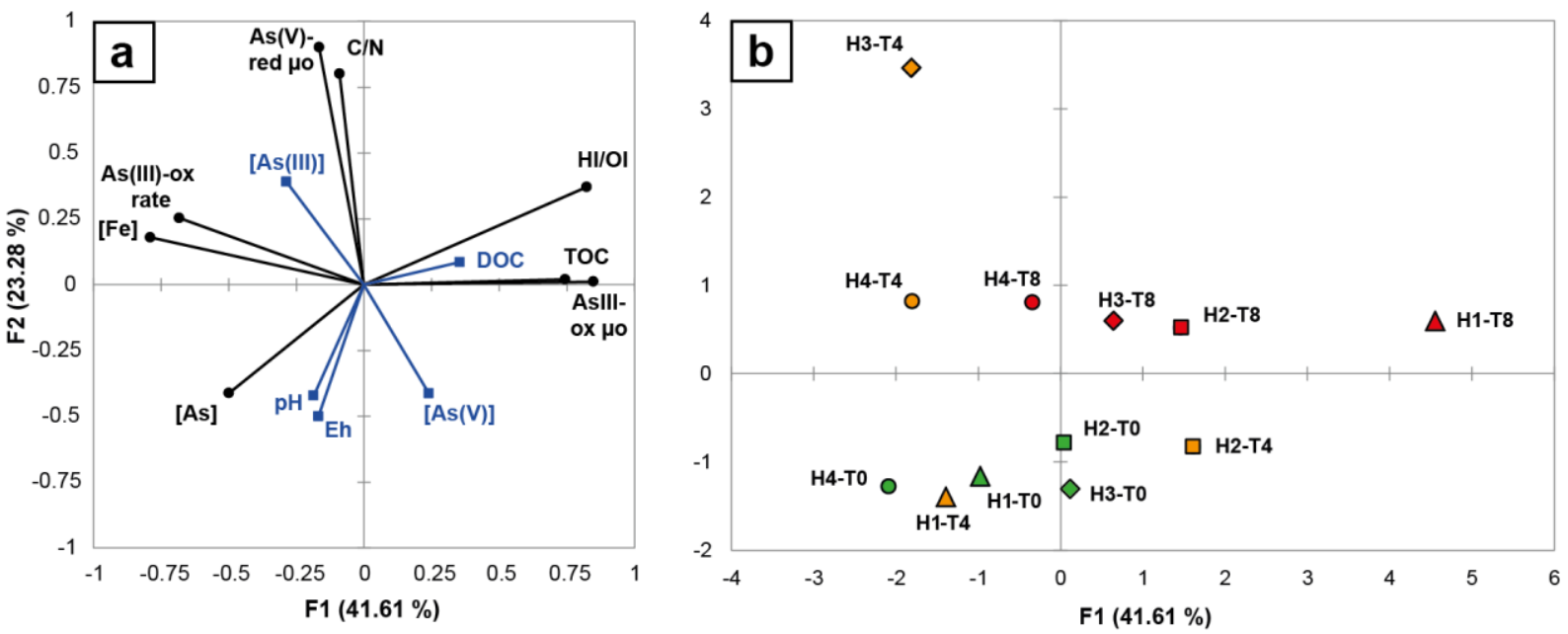

Fig.6. PCA using biogeochemical parameters of soil samples (black) with geochemical parameters of soil solutions (from Thouin et al.,, 2017) as supplementary data (blue). a: Correlation circle showing variable relationships. b: Factorial plan showing samples. (ox: oxidizing; red: reducing; $\mu$ o: microorganisms). Pearson correlation matrix was presented in SM6.

351 As previously observed, the As(III) oxidation rate seems to be negatively correlated with As(III)-oxidizing microorganism concentrations $(\mathrm{p}=-0.50)$ and with DOC $(\mathrm{p}=-0.53)$ and HI/OI $(\mathrm{p}=-0.50)$ (Fig.6.a). This distribution was brought by principal component F1, which represented about $40 \%$ of total variability. For this component, the surface soil (H1-T8), as the end member, is pulled to the right (Fig.6.b) due to the combined effect of DOC, TOC, HI/OI, and As(III)-oxidizing microorganism concentrations. This level was the most impacted by the addition of forest litter. The sample distribution along the principal component F1 shows the overall effect of the litter on the entire mesocosm, with an enhanced influence towards the right from T4 to T8. Moreover, the distribution of T8 samples clearly depends on their depth because, as previously discussed, the deeper level was less impacted by the addition of OM.

360 Principal component F2 accounts for $23 \%$ of total variability. The concentration of As(V)-reducing microorganisms and the $\mathrm{C} / \mathrm{N}$ ratio were correlated $(\mathrm{p}=0.59)$ and were the primary contributors to $\mathrm{F} 2$. The previously mentioned positive effect of soil saturation on As(V)-reducing microorganisms is expressed by the upward translation of samples $\mathrm{H} 3$ and $\mathrm{H} 4$ between T0 and T4 along the F2 axis (Fig.6.b). Bioavailable OM may stimulate the $\mathrm{As}(\mathrm{V})$-reducing activity of soil microorganisms under aerobic conditions (Yamamura et al., 2009) because the $\mathrm{As}(\mathrm{V})$-reducing mechanism linked to the As resistance system consumes energy. In our study, concentrations of $\mathrm{As}(\mathrm{V})$-reducing microorganisms increased in the non-saturated soil after the addition of fragmented litter. However, $\mathrm{As}(\mathrm{V})$-reducing microorganisms were correlated to the $\mathrm{C} / \mathrm{N}$ ratio $(\mathrm{p}=0.59)$ but were not correlated to total OM concentrations (TOC, $\mathrm{p}=-0.18$; DOC, $\mathrm{p}=-0.09$ ). The relationship between As(V)- 
reducing microorganism concentrations in the soil and OM qualities and quantities cannot be confirmed here.

370 Finally, the quantity of As(V)-reducing microorganisms was correlated with As(III) concentrations in soil 371 interstitial water $(\mathrm{p}=0.76)$ suggesting that microbial As-reducing activity was promoted by soil saturation. 372 However, the overall proportion of As(III) in interstitial water remained lower that of $\mathrm{As}(\mathrm{V})$ (10 to $20 \%$, Thouin 373 et al., 2017).

374 The present experiment differs from previous studies by two main aspects: (1) the extreme level of metals and As 375 concentrations, that resemble those found in mining wastes (Drewniak et al., 2008) but without the high 376 concentration in sulfur species, and (2) the fact that in spite of water saturation and addition or OM, the redox potential did not reach very low values. Weber et al. (2010) observed a decrease of redox potential down to $0 \mathrm{mV}$ 378 in the porewater of their contaminated surface soil after 20 days of flooding with artificial river water, with a 379 simultaneous strong reduction of $\mathrm{As}(\mathrm{V})$, whereas in our experiment, the redox potential always remained higher 380 than $+100 \mathrm{mV}$ (Thouin et al., 2017). As a fact, most of the reported studies about redox dynamic were performed 381 with soils or sediments less contaminated than the "Place-à-Gaz" material: 300 ppm As in a polluted floodplain 382 soil (Weber et al., 2010), 375 ppm As in an artificially polluted soil (Couture et al., 2015), 63 ppm As in a 383 contaminated sediment (Moon et al., 2017) compared with 100000 ppm As in our soil. Thus, the present 384 experiment provides information about microbial As transformation in a biogeochemical environment that was not previously explored in variable redox conditions. Thouin et al. (2016) found that elevated toxic element concentrations $(\mathrm{Cu}, \mathrm{Pb}, \mathrm{Zn}, \mathrm{As})$ seemed to have exerted a selective pressure on the microbial communities, with higher As(III)-oxidizing rates and lower microbial activity involved in carbon mineralization of the microbial populations from the most polluted zone of the site. Thus, phenomena linked to high concentrations of metals and arsenic may have attenuated the decrease of redox potential linked to oxygen consumption in the saturated level, while OM was provided, compared with less polluted environments. Up to now, all As(III)-oxidizing bacteria 391 isolated from soils were heterotrophs or facultative autotrophs (Inskeep et al., 2007; Bachate et al., 2012; Bahar et 392 al., 2013; Dong et al., 2014). The increasing amount of OM and its quality therefore promoted the growth of 393 As(III)-oxidizing microorganisms. However, several studies have shown that elevated concentrations of 394 bioavailable OM negatively impact As(III)-oxidizing bacterial activity (Challan-Belval et al., 2009; Bachate et al., 395 2012; Lescure et al., 2016). The opposite trend of overall As(III) oxidizing rate with increasing As(III)-oxidizing 396 microorganisms concentration $(\mathrm{p}=-0.50)$ and with the quality and quantity of OM seems to confirm the inhibiting 397 effect of OM on the specific activity of As(III)-oxidizing microbes. However, globally, As(III) oxidizing 398 microorganisms remained active in presence of OM, even in the saturated zones of the mesocosm, in accordance 
with the predominance of $\mathrm{As}(\mathrm{V})$ in the interstitial water all along the experiment and with the formation of mimetite. This original phenomenon could result from the particular balance between As and OM microbial transformations in the presence of extremely high concentrations of toxic contaminants.

\section{Conclusion}

The mesocosm experiment provided important information about the mineralogical evolution and stability of As and heavy metal mineral carriers present in the highly-polluted soil at the "Place-à-Gaz" site, as it underwent environmental changes. $\mathrm{As}, \mathrm{Cu}$, and $\mathrm{Zn}$-bearing amorphous phases were altered under saturated conditions. Related to this alteration process, SEM results suggest a mechanism of dissolution and re-precipitation of iron in the form of amorphous oxides that may be a secondary sink for As and metals. In contrast, no traces of alteration were observed on crystallized arsenate minerals present in the soil at the beginning of the experiment. However, the formation of mimetite, a lead arsenate chloride mineral, was detected in water saturated zones. This phenomenon contributed to the immobilization of $\mathrm{As}(\mathrm{V})$ and $\mathrm{Pb}$, but was limited by the low $\mathrm{Pb}$ concentration of the soil solution.

The input of $\mathrm{OM}$ contributed to the growth of both $\mathrm{As}(\mathrm{III})$-oxidizing and $\mathrm{As}(\mathrm{V})$-reducing microorganisms and negatively impacted the overall As(III) oxidation efficiency. This last phenomenon may be related to both the inhibition of microbial As(III)-oxidizing activities and the development of As(V)-reducing microorganisms. However, As(III)-oxidizing activity remained the major microbial-related phenomenon even in the saturated zones. Altogether, results from the mesocosm experiment show that water saturation of the "Place-à-Gaz" soil during high precipitation episodes is likely to promote the release of $\mathrm{Zn}$ and As into the water compartment. However, microbial As(III) oxidation activities, adsorption of $\mathrm{As}(\mathrm{V})$ on $\mathrm{HFO}$ and precipitation of mimetite are all processes observed during the experiment that contribute to partial immobilization of As, i.e. a decrease of total soluble As. The elucidation of these geochemical and biogeochemical processes at the mesocosm scale will contribute to more precise evaluations of the risks associated with these types of polluted sites and to better design management strategies.

\section{Acknowledgments}

This work was co-funded by the Région Centre Val-de-Loire and BRGM (convention 00087485) and the Labex Voltaire (ANR-10-LABX-100-01). The authors wish to thank Philippe Penhoud, Marielle Hatton, and Rachel Boscardin (ISTO) for XRD, CHNS and Rock-Eval results, Pascal Auger (BRGM) for Niton analyses, and Daniel Hube (BRGM) who introduced the environmental issue and provided the polluted material. 


\section{References}

429 Bachate, S.P., Khapare, R.M., and Kodam, K.M. (2012). Oxidation of arsenite by two $\beta$-proteobacteria isolated 430 from soil. Applied Microbiology and Biotechnology 93, 2135-2145.

431 DOI: $10.1007 / \mathrm{s} 00253-011-3606-7$

432 Bahar, M.M., Megharaj, M., and Naidu, R. (2013). Kinetics of arsenite oxidation by Variovorax sp. MM-1 isolated 433 from a soil and identification of arsenite oxidase gene. Journal of Hazardous Materials 262, 997-1003.

434 DOI: 10.1016/j.jhazmat.2012.11.064

435 Bajda, T., Szmit, E., and Manecki, M. (2006). Removal of As (V) from solutions by precipitations of mimetite $436 \mathrm{Pb5}$ (AsO4) 3Cl. Environmental Engineering, 119-124.

437 Bajda, T. (2010). Solubility of mimetite $\mathrm{Pb}_{5}\left(\mathrm{AsO}_{4}\right)_{3} \mathrm{Cl}$ at 5-55 C. Environmental Chemistry 7, 268.

438 DOI: $10.1071 / \mathrm{EN} 10021$

439 Battaglia-Brunet, F., Dictor, M.-C., Garrido, F., Crouzet, C., Morin, D., Dekeyser, K., Clarens, M., and Baranger, 440 P. (2002). An arsenic(III)-oxidizing bacterial population: selection, characterization, and performance in reactors. 441 Journal of Applied Microbiology 93, 656-667.

442 DOI: $10.1046 /$ j.1365-2672.2002.01726.x

443 Bausinger, T., and Preuß, J. (2005). Environmental remnants of the First World War: Soil contamination of a 444 burning ground for arsenical Ammunition. Bulletin of Environmental Contamination and Toxicology 74, 10454451053.

446 DOI: $10.1007 / \mathrm{s} 00128-005-0686-\mathrm{z}$

447 Bausinger, T., Bonnaire, E., and Preuß, J. (2007). Exposure assessment of a burning ground for chemical 448 ammunition on the Great War battlefields of Verdun. Science of The Total Environment 382, $259-271$.

449 DOI: 10.1016/j.scitotenv.2007.04.029

450 Challan-Belval, S., Garnier, F., Michel, C., Chautard, S., Breeze, D., and Garrido, F. (2009). Enhancing pozzolana 451 colonization by As(III)-oxidizing bacteria for bioremediation purposes. Applied Microbiology and Biotechnology $45284,565-573$.

453 DOI: $10.1007 / \mathrm{s} 00253-009-2077-6$

454 Couture, R.-M., Charlet, L., Markelova, E., Madé, B., and Parsons, C.T. (2015). On-Off Mobilization of 455 Contaminants in Soils during Redox Oscillations. Environmental Science \& Technology. 49, 3015-3023.

456 DOI: $10.1021 /$ es5061879

457 Deneele, D (2002). Caractérisation, simulations expérimentales et thermodynamiques de l'altération de déchets 458 vitreux: les scories de première fusion de plomb et de zinc, University Ph.D. Thesis, University of Lille 1, France, $4592002,198 \mathrm{pp}$.

460 Disnar, J.R., Guillet, B., Keravis, D., Di-Giovanni, C., and Sebag, D. (2003). Soil organic matter (SOM) 461 characterization by Rock-Eval pyrolysis: scope and limitations. Organic Geochemistry 34, $327-343$.

462 DOI: 10.1016/S0146-6380(02)00239-5

463 Dixit, S., and Hering, J.G. (2003). Comparison of arsenic(V) and arsenic(III) sorption onto iron oxide minerals: 464 implications for arsenic mobility. Environmental Science and Technology 37, 4182-4189.

465 DOI: $10.1021 / \mathrm{es} 030309 \mathrm{t}$

466 Dong, D., Ohtsuka, T., Dong, D.T., and Amachi, S. (2014). Arsenite oxidation by a facultative 467 chemolithoautotrophic Sinorhizobium sp. KGO-5 isolated from arsenic-contaminated soil. Bioscience, 468 Biotechnology, and Biochemistry 78, 1963-1970. 
470 Drewniak, L., Matlakowska R., Sklodowska, A. (2008). Arsenite and Arsenate Metabolism of Sinorhizobium sp. 471 M14 Living in the Extreme Environment of the Zloty Stok Gold Mine. Geomicrobiology Journal 25, 363-370.

472 DOI: 10.1080/01490450802402836

473 Drewniak, L., and Sklodowska, A. (2013). Arsenic-transforming microbes and their role in biomining processes. 474 Environmental Science and Pollution Research20, 7728-7739.

475 DOI: $10.1007 / \mathrm{s} 11356-012-1449-0$

476 Dutra, A.J.B., Paiva, P.R.P., and Tavares, L.M. (2006). Alkaline leaching of zinc from electric arc furnace steel 477 dust. Minerals Engineering 19, 478-485.

478 DOI: 10.1016/j.mineng.2005.08.013

479

480

481

Ettler, V., Komárková, M., Jehlička, J., Coufal, P., Hradil, D., Machovič, V., and Delorme, F. (2004). Leaching of lead metallurgical slag in citric solutions implications for disposal and weathering in soil environments. Chemosphere 57, 567-577.

DOI: $10.1016 /$ j.chemosphere.2004.07.022

Inskeep, W. P., Macur, R. E., Hamamura, N. H., Warelow, T. P., Ward, S. A., Santini, J. M. (2007). Detection, diversity and expression of aerobic bacterial arsenite oxidase genes. Environmental Microbiology 9, 934-943.

DOI: $10.1111 /$ j.1462-2920.2006.01215.x

Moon, H. S., Kim, B. A., Hyun, S. Y., Lee Y.-H., Shin D. (2017). Effect of the redox dynamics on microbialmediated As transformation coupled with $\mathrm{Fe}$ and $\mathrm{S}$ in flow-through sediment columns. Journal of Hazardous Materials 329, 280-289.

DOI: 10.1016/j.jhazmat.2017.01.034

Juillot, F., Morin, G., Ildefonse, P., Trainor, T.P., Benedetti, M., Galoisy, L., Calas, G., and Brown, G.E. (2003). Occurrence of $\mathrm{Zn} / \mathrm{Al}$ hydrotalcite in smelter-impacted soils from northern France: Evidence from EXAFS spectroscopy and chemical extractions. American Mineralogist 88, 509-526.

DOI: $10.2138 / \mathrm{am}-2003-0405$

Keiluweit, M., Nico, P.S., Johnson, M.G., and Kleber, M. (2010). Dynamic molecular structure of plant biomassderived black carbon (biochar). Environmental Science \& Technology 44, 1247-1253.

DOI: $10.1021 /$ es9031419

Kuai, L., Nair A. A., Polz M. F. (2001) Rapid and simple method for the Most-Probable-Number estimation of arsenic-reducing bacteria. Applied and Environmental Microbiology 67, 3168-3173.

DOI: 10.1128/AEM.67.7.3168-3173.2001

Kumpiene, J., Ragnvaldsson, D., Lövgren, L., Tesfalidet, S., Gustavsson, B., Lättström, A., Leffler, P., and Maurice, C. (2009). Impact of water saturation level on arsenic and metal mobility in the Fe-amended soil. Chemosphere 74, 206-215.

DOI: $10.1016 /$ j.chemosphere.2008.09.068

Lafargue, E., Marquis, F., and Pillot, D. (1998). Rock-Eval 6 Applications in Hydrocarbon Exploration, Production, and Soil Contamination Studies. Rev. Inst. Fr. Pét. 53, 421-437.

DOI: $10.2516 /$ ogst:1998036

Le Forestier, L., Libourel, G. (2008) High temperature behavior of electrostatic precipitator ash from municipal solid waste combustors. Journal of Hazardous Materials 154, 373-380.

DOI: $10.1016 /$ j.jhazmat.2007.10.034

Lescure T., Carpentier A., Battaglia-Brunet F., Morel-Desrosiers N.. (2013) Oxidation of As(III) by the Bacterial Community of a Marine Sediment Monitored by Microcalorimetry. Geomicrobiology Journal 30, 540-548. 
513 Lescure, T., Moreau, J., Charles, C., Ben Ali Saanda, T., Thouin, H., Pillas, N., Bauda, P., Lamy, I., and Battaglia-

514 Brunet, F. (2016). Influence of organic matters on AsIII oxidation by the microflora of polluted soils.

515 Environmental Geochemistry and Health 38, 911-925.

516 DOI: $10.1007 / \mathrm{s} 10653-015-9771-3$

Magalhães, M.C.F., and Silva, M.C.M. (2003). Stability of lead(II) arsenates. Monatshefte Für Chemie / Chemical Monthly 134(5), 735-743.

de Mello, J.W.V., Talbott, J.L., Scott, J., Roy, W.R., and Stucki, J.W. (2007). Arsenic speciation in arsenic-rich Brazilian soils from gold mining sites under anaerobic incubation. Environmental Science and Pollution Research - International 14, 388-396.

523 DOI: $10.1065 /$ espr2006.08.330

Parsons, C.T., Couture, R.-M., Omoregie, E.O., Bardelli, F., Greneche, J.-M., Roman-Ross, G., and Charlet, L. (2013). The impact of oscillating redox conditions: Arsenic immobilisation in contaminated calcareous floodplain soils. Environmental Pollution 178, 254-263.

527 DOI : $10.1016 /$ j.envpol.2013.02.028

528 Pisciella, P., Crisucci, S., Karamanov, A., and Pelino, M. (2001). Chemical durability of glasses obtained by vitrification of industrial wastes. Waste Management 21, 1-9.

530 DOI: 10.1016/S0956-053X(00)00077-5

Puziewicz, J., Zainoun, K., and Bril, H. (2007). Primary phases in pyrometallurgical slags from a zinc-smelting waste dump, swietochlowice, upper silesia, poland. The Canadian Mineralogist 45, 1189-1200.

DOI: $10.2113 /$ gscanmin.45.5.1189

Saenger, A., Cécillon, L., Poulenard, J., Bureau, F., De Daniéli, S., Gonzalez, J.-M., and Brun, J.-J. (2015). Surveying the carbon pools of mountain soils: A comparison of physical fractionation and Rock-Eval pyrolysis. Geoderma 241-242, 279-288.

537 DOI: $10.1016 /$ j.geoderma.2014.12.001

Schneider, M.P.W., Hilf, M., Vogt, U.F., and Schmidt, M.W.I. (2010). The benzene polycarboxylic acid (BPCA) pattern of wood pyrolyzed between $200^{\circ} \mathrm{C}$ and $1000^{\circ} \mathrm{C}$. Organic Geochemistry $41,1082-1088$. DOI: 10.1016/j.orggeochem.2010.07.001

Seignez, N., Gauthier, A., Bulteel, D., Buatier, M., Recourt, P., Damidot, D., and Potdevin, J.L. (2007). Effect of $\mathrm{Pb}$-rich and Fe-rich entities during alteration of a partially vitrified metallurgical waste. Journal of Hazardous Materials 149, 418-431.

545 Stolz, J., Basu, P., and Oremland, R. (2002). Microbial transformation of elements: the case of arsenic and 546 selenium. International Microbiology 5, 201-207.

547 DOI: 10.1007/s10123-002-0091-y

548 Swallow, K.C., Hume, D.N., and Morel, F.M.M. (1980). Sorption of copper and lead by hydrous ferric oxide. 549 Environmental Science and Technology 14, 1326-1331.

550 DOI: $10.1021 / \mathrm{es} 60171 \mathrm{a} 003$

551 Thouin, H., Le Forestier, L., Gautret, P., Hube, D., Laperche, V., Dupraz, S., and Battaglia-Brunet, F. (2016). 552 Characterization and mobility of arsenic and heavy metals in soils polluted by the destruction of arsenic-containing 553 shells from the Great War. Science of The Total Environment 550, 658-669. 
555 Thouin, H., Battaglia-Brunet, F., Gautret, P., Le Forestier, L., Breeze, D., Séby, F., Norini, M.-P., and Dupraz, S. 556 (2017). Effect of water table variations and input of natural organic matter on the cycles of $\mathrm{C}$ and $\mathrm{N}$, and mobility 557 of $\mathrm{As}, \mathrm{Zn}$ and $\mathrm{Cu}$ from a soil impacted by the burning of chemical warfare agents: A mesocosm study. Science of

558 The Total Environment 595, 279-293.

559 DOI: $10.1016 /$ j.scitotenv.2017.03.218

560 Tiedje, J.M., Asuming-Brempong, S., Nüsslein, K., Marsh, T.L., and Flynn, S.J. (1999). Opening the black box of 561 soil microbial diversity. Applied Soil Ecology 13, 109-122.

562 DOI: $10.1016 /$ S0929-1393(99)00026-8

563 Twidwell, L.G., Plessas, K.O., Comba, P.G., and Dahnke, D.R. (1994). Removal of arsenic from wastewaters and 564 stabilization of arsenic bearing waste solids: Summary of experimental studies. Journal of Hazardous Materials $56536,69-80$.

566 DOI: 10.1016/0304-3894(93)E0054-6

567 Weber F. A., Hofacker A. F., Kretzschmar R. (2010). Temperature dependence and coupling of iron and arsenic 568 reduction and release during flooding of a contaminated soil. Environmental Science and Technology 44, 116569122.

570 DOI: $10.1021 / \mathrm{es} 902100 \mathrm{~h}$

571 Vereš, J. (2014). Determination of zinc speciation in metallurgical wastes by various analytical methods.

572 International Journal, 5(5).

573 Wolf, M., Lehndorff, E., Wiesenberg, G.L.B., Stockhausen, M., Schwark, L., and Amelung, W. (2013). Towards 574 reconstruction of past fire regimes from geochemical analysis of charcoal. Organic Geochemistry 55, 11-21.

575 DOI: 10.1016/j.orggeochem.2012.11.002

576

577

578

579

580

581

582

583

584

585

Xiao K.-Q., Li L. G., Ma L. P., Zhang S. Y., Bao P., Zhang T., Zhu Y.-G. (2016). Metagenomic analysis revealed highly diverse microbial arsenic metabolism genes in paddy soils with low-arsenic contents. Environmental Pollution 211, 1-8.

DOI: $10.1016 /$ j.envpol.2015.12.023

Yamamura, S., Watanabe, M., Yamamoto, N., Sei, K., and Ike, M. (2009). Potential for microbially mediated redox transformations and mobilization of arsenic in uncontaminated soils. Chemosphere 77, 169-174.

DOI: 10.1016/j.chemosphere.2009.07.071

Zobrist, J., Dowdle, P.R., Davis, J.A., and Oremland, R.S. (2000). Mobilization of arsenite by dissimilatory reduction of adsorbed arsenate. Environmental Science and Technology 34, 4747-4753.

DOI: 10.1021/es001068h 